\title{
Successful repeated thrombolysis in a patient with HeartWare thrombosis - the importance of Doppler flow pattern
}

\author{
Lech Paluszkiewicz, Michiel Morshuis, Kavous Hakim-Meibodi, Stephan Ensminger, Jan Gummert \\ Department of Thoracic and Cardiovascular Surgery, Heart and Diabetes Center North Rhine-Westphalia, \\ Ruhr University Bochum, Bad Oeynhausen, Germany
}

Kardiochirurgia i Torakochirurgia Polska 2014; 11 (4): 428-431

\begin{abstract}
Here we present a patient after implantation of a left ventricular assist device (HeartWare) for destination therapy complicated by recurrent thrombosis of the device. At 14 months after implantation, the patient presented with a pump thrombosis after an INR incompliance period. A surgical pump exchange was performed and the patient recovered uneventfully. Five months later a pump thrombosis occurred again, and the patient refused surgery. Systemic thrombolysis was carried out this time. Three and 6 months later the same clinical picture was presented again, and repeat thrombolysis was performed successfully. The patient was discharged and has remained stable since, without any symptoms of thrombosis of the device.

Key words: thrombosis, circulatory assist devices, LVAD, echocardiography, heart failure operations.
\end{abstract}

\section{Streszczenie}

W pracy przedstawiono przypadek pacjentki, która w ramach terapii docelowej została poddana wszczepieniu systemu wspomagającego lewą komorę serca (left ventricular assist device - LVAD; HeartWare ${ }^{\circledR}$ ), a u której stwierdzono nawracającą zakrzepicę urządzenia. Po 14 miesiącach od wszczepienia urządzenia, po okresie nieadekwatnej antykoagulacji po raz pierwszy rozpoznano zakrzepicę systemu. Pacjentkę poddano reoperacji i wymieniono urządzenie. Przebieg pooperacyjny był niepowikłany, stan kliniczny pacjentki pozostawał stabilny. Po 5 miesiącach od zabiegu ponownie rozpoznano zakrzepicę. Tym razem pacjentka odmówiła poddania się kolejnej operacji. W związku z tym przeprowadzono systemową trombolizę z dobrym efektem klinicznym. Po 3 i 6 miesiącach od leczenia trombolitycznego, po kolejnych okresach wahań poziomu INR (international normalized ratio), powróciły objawy zakrzepicy. Powtórzono leczenie trombolityczne, uzyskując dobry efekt kliniczny. Pacjentkę zwolniono ze szpitala w dobrym stanie ogólnym, dalszy przebieg kliniczny był niepowikłany, bez objawów zakrzepicy.

Słowa kluczowe: zakrzepica, urządzenie wspomagające krążenie, LVAD, echokardiografia, operacje niewydolności serca.

plantation of a HeartWare LVAD (HeartWare International, Inc, Framingham, MA, USA) for destination therapy as she was initially not a suitable candidate for heart transplantation. The initial postoperative period was uneventful, and the patient was doing well for 14 months. Subsequently she presented with signs of congestive heart failure and a history of a recent international normalized ratio (INR) incompliance period. Indeed, significant variations of the INR levels were observed on the days prior to hospital admission. Clinical examination and diagnostic results confirmed the initial diagnosis of device thrombosis. After a careful analysis of the therapeutic options and an intensive discussion with the patient, a surgical pump exchange was recommended.

Address for correspondence: Lech Paluszkiewicz, MD, HDZ-NRW, Department of Thoracic and Cardiovascular Surgery, Georgstr. 11, 32545 Bad Oeynhausen, Germany, phone: 00495731 973538, fax: 00495731 971871, e-mail: Ipaluszkiewicz@hdz-nrw.de 
The surgical pump exchange was performed successfully and a thrombus was found inside the device. The patient recovered well from surgery, the postoperative period was uneventful, and the patient was discharged from hospital.

Five months later the patient presented with symptoms of heart failure and signs of pump thrombosis. After carefully estimating the risk of a second surgical pump exchange, we decided to perform a systemic thrombolysis using tenecteplase on a body weight basis [1]. The maximum dose of 10000 units (50 mg) of tenecteplase was administered as a single intravenous bolus in 5 to 10 seconds. Infusion of heparin was titrated to maintain an activated partial prothrombin time of 50 to 60 seconds. The antiplatelet therapy was continued after thrombolysis. The clinical symptoms of heart failure of the patient improved within hours, and biochemical parameters returned to normal.

Three months later the patient presented again with a history of another episode of INR incompliance. Levels of free hemoglobin and lactate dehydrogenase were elevated significantly. At this time an intensive discussion about

Tab. I. Clinical data and results of echocardiographic examination

\begin{tabular}{lcc} 
Parameter & At admission & After thrombolysis \\
BP mean $(\mathrm{mmHg})$ & 70 & 71 \\
\hline RPM $(1 / \mathrm{min})$ & 2400 & 2400 \\
\hline Free $\mathrm{Hb}(\mathrm{mg} / \mathrm{l})$ & 800 & 400 \\
\hline LDH $(\mathrm{U} / \mathrm{l})$ & 2700 & 1152 \\
\hline LVEDD $(\mathrm{mm})$ & 65 & 55 \\
\hline LVESD $(\mathrm{mm})$ & 65 & 49 \\
\hline Outflow d $(\mathrm{cm} / \mathrm{s})$ & 40 & 80 \\
\hline Outflow s $(\mathrm{cm} / \mathrm{s})$ & 130 & 180
\end{tabular}

BP mean - mean blood pressure, RPM - device rotational speed: rate per minute, Free $\mathrm{Hb}(\mathrm{mg} / \mathrm{l})$ - free hemoglobin level, LDH - lactate dehydrogenase, LVEDD - left ventricular end diastolic diameter, LVESD - left ventricular end systolic diameter, Outflow $\mathrm{d}$ - diastolic flow velocity in the outflow cannula, Outflow s - systolic flow velocity in the outflow cannula
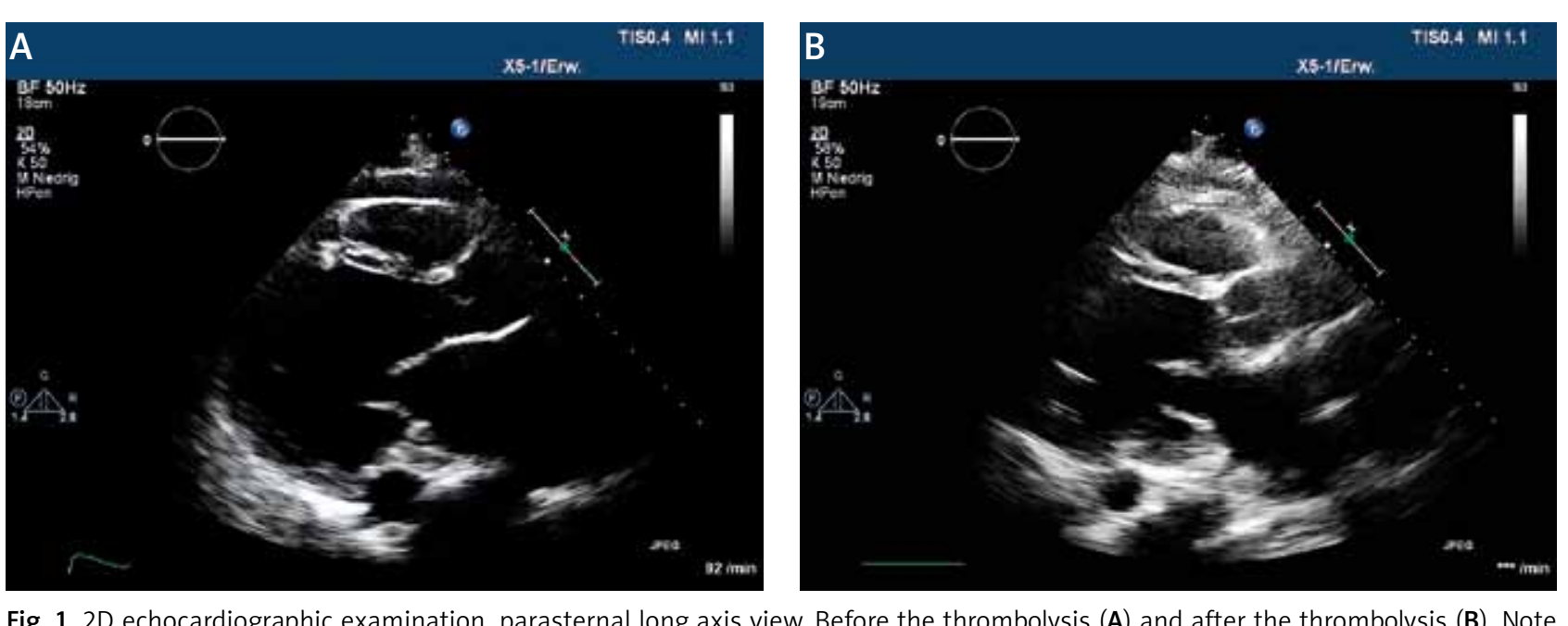

Fig. 1. $2 \mathrm{D}$ echocardiographic examination, parasternal long axis view. Before the thrombolysis (A) and after the thrombolysis (B). Note significantly smaller diameter of the left ventricle after thrombolysis as a sign of left ventricle unloading

therapeutic options was held with the patient, and a repeat surgical pump exchange was recommended. However, the patient refused repeat surgery, and therefore a systemic thrombolysis was performed again successfully using 10000 units of tenecteplase. The patient recovered uneventfully and was discharged from the hospital. She was doing well for the next six months until the last admission.

Having done well for six months the patient was again readmitted to the hospital with the picture of congestive heart failure and suspicion of pump thrombosis. In addition, an increase of free hemoglobin and lactate dehydrogenase levels was noted (Table I). On echocardiographic examination, marked dilation of the left ventricle and a regular opening movement of the aortic valve were seen (Fig. 1A), and the diastolic flow velocity in the outflow cannula was significantly decreased (Fig. 2A). Taken together, clinical examination and diagnostic results confirmed our initial diagnosis of device thrombosis. This time the patient refused surgery again, and we decided to perform thrombolysis for the third time with 10000 units of tenecteplase. The clinical status of the patient improved, and 24 hours after initiation of therapy levels of free hemoglobin and lactate dehydrogenase decreased (Table I). On echocardiographic examination a decrease of the left ventricular diameter and intermittent opening of the aortic valve were noted (Fig. 1B). The diastolic velocity of flow pattern in the outflow cannula increased significantly (Fig. 2B). The patient was discharged uneventfully after 5 days and remains stable after 6 months.

The diagnosis of pump-associated thrombosis is a challenging one, and in most cases it is made on a clinical basis (heart failure, hemolysis, increase of free hemoglobin and lactate dehydrogenase levels) or by analyzing the device parameters (pump rotor speed, increase of power consumption, reduction of pulsatility index, abnormal reduction or increase of VAD flow, differing from the patient's baseline). A transthoracic echocardiographic examination especially analyzing the Doppler flow pattern can be useful in early diagnosis and monitoring of the treatment of pump

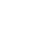



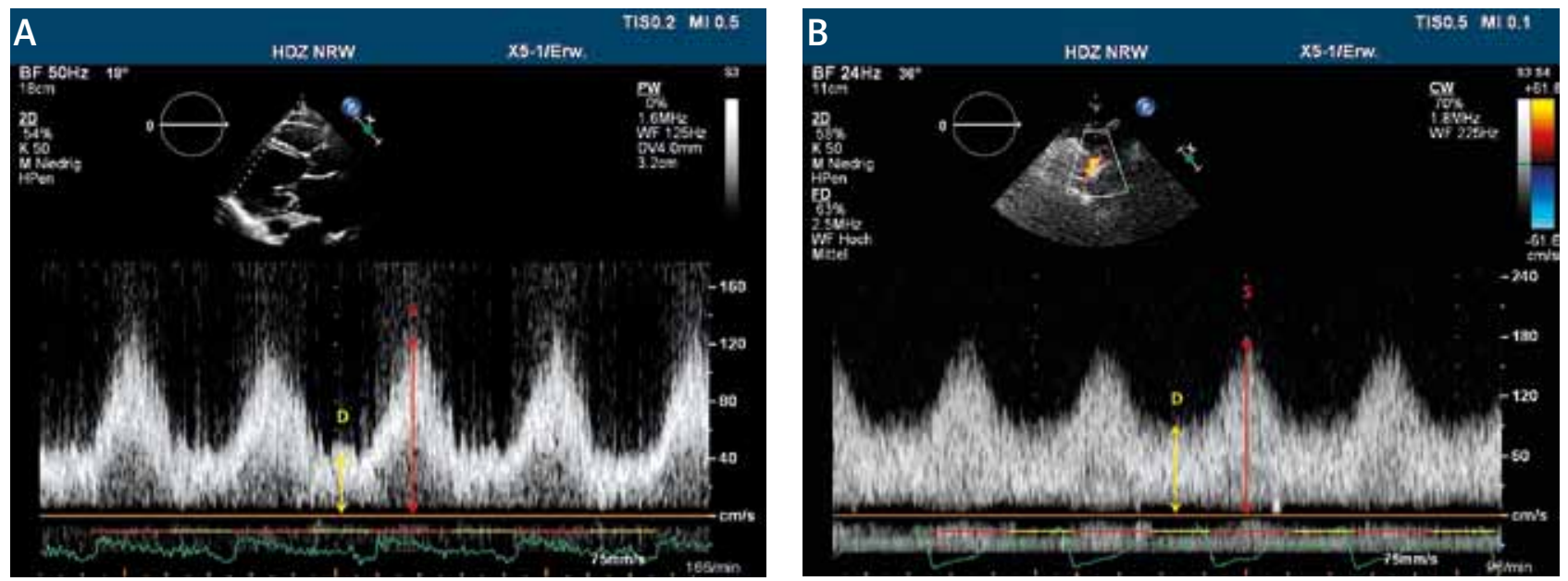

Fig. 2. PW and CW Doppler echocardiographic examination before and after the thrombolysis within the outflow cannula. The flow consists of a basal diastolic flow (yellow arrow) and the systolic flow (marked with red arrow). Note relatively low flow velocity before thrombolysis (A). After the thrombolysis (B) an increase in flow velocity was noted in both inflow and outflow cannulas. Note a significant increase in diastolic flow velocity (yellow arrow) after the treatment. S - systole (marked in red), red arrow shows systolic flow, D - diastole (marked in yellow), yellow arrow shows diastolic flow

thrombosis [2]. After the diagnosis of device thrombosis is established there are two possible treatment options: surgery or thrombolytic therapy. The first option includes heart transplantation or surgical pump exchange, the second systemic or local thrombolytic therapy. However, even the high-urgent (HU) heart transplantation is not a real option nowadays because of an excessively long waiting time. In our experience, whenever possible, a surgical pump exchange should be the primary method of choice for device thrombosis as it is the only therapeutic option ensuring complete removal of the thrombus. However, the surgical pump exchange with or without cardiopulmonary bypass is associated with mortality or complications such as bleeding or wound infection. This procedure was also performed during the first episode of device thrombosis in this patient, and it has been shown by our group that it can be performed safely with acceptable risk for the patient [3]. The off-pump exchange seems to be associated with a smaller operative risk [3], but its disadvantage is the obstructed and reduced vision inside the left ventricular cavity to rule out ventricular thrombi. However, numbers of treated patients are still fairly small, and therefore a final recommendation on which strategy is the superior approach is not possible at this time. Under special circumstances such as in this case even a repeat thrombolytic therapy can be performed effectively under tightly controlled conditions. Its side effects are major bleeding, hypercoagulability and recurrence of thrombosis as reported several times in the literature [4-6]. However, there is no clear evidence in favor of local vs. systemic thrombolysis, as both methods have systemic side effects and local administration carries a significant risk of catheter ingestion in the device. The special situation of our patient and the fact that she refused repeat surgery left us with the only option to perform a repeat thrombolysis during the following episodes of device thrombosis. At this stage it is unclear whether thrombosis recurrence was caused by insufficient thrombolysis or by a low INR level prior to each episode of thrombosis and hospital admission.

Finally, as of today we have managed to continue support in spite of triple thrombolysis without serious complications for another 15 months since the pump exchange. During this time the patient's compliance has improved, she has lost $15 \mathrm{~kg}$ in body weight, and her psychological status has improved. She now has a realistic chance to become a transplant candidate.

\section{Conclusions}

Here we have demonstrated that early diagnosis using echocardiography, careful INR management and appropriate treatment are the keys to successful long-term LVAD patient support. As there is currently no clear evidence which method of treatment is superior for the patient, decisions should be made on an individual basis such as in our case. Therefore, even under these circumstances with a postoperative surgical pump exchange and repeated systemic thrombolysis, the patient could be discharged successfully and finally did well.

\section{Disclosure}

Authors report no conflict of interest.

\section{References}

1. Dunn CJ, Goa KL. Tenecteplase: a review of its pharmacology and therapeutic efficacy in patients with acute myocardial infarction. Am J Cardiovasc Drugs 2001; 1: 51-66.

2. Paluszkiewicz L, Gürsoy D, Spiliopoulos S, Dogan G, Daliakopoulos S, Tenderich M, Körfer R, Tenderich G. HeartMate II ventricular assist device thrombosis-an echocardiographic approach to diagnosis: can Doppler evaluation of flow be useful? J Am Soc Echocardiogr 2011; 24: 350.e1-4. 
3. Aissaoui N, Borgermann J, Gummert J, Morshuis M. HeartWare continuousflow ventricular assist device thrombosis: the Bad Oeynhausen experience. J Thorac Cardiovasc Surg 2012; 143: e37-39.

4. Rothenburger M, Wilhelm MJ, Hammel D, Schmidt C, Tjan TDT, Böcker D, Scheld HH, Schmid C. Treatment of thrombus formation associated with the MicroMed DeBakey VAD using recombinant tissue plasminogen activator. Circulation 2002; 106: 189-192.
5. Tang GHL, Michael C, Kim MC, Pinney, SP, Anyanwu AC. Failed repeated thrombolysis requiring left ventricular assist device pump exchange Short title: Failed thrombolysis and LVAD pump exchange. Catheter Cardiovasc Interv 2013; 81: 1072-1074.

6. Kiernan MS, Pham DT, Denofrio D, Kapur NK. Management of HeartWare left ventricular assist device thrombosis using intracavitary thrombolytics. J Thorac Cardiovasc Surg 2011; 142: 712-714. 